\title{
SOVEREIGNTY AND STATE OF EXCEPTION IN WILLIAM GOLDING'S LORD OF THE FLIES
}

Araştırma Makalesi / Research Article

\begin{abstract}
Altaç, İ., S. (2020). Sovereignty and State of Exception in William Golding's Lord of the Flies. Nevşehir Hacı Bektaş Veli Üniversitesi SBE Dergisi, 10(1), 52-60.
\end{abstract}

Geliş Tarihi: 10.02.2020

Kabul Tarihi:28.04.2020

E-ISSN: $2149-3871$

\author{
Dr. İsmail Serdar ALTAÇ \\ Nevşehir Hacı Bektaş Veli Üniversitesi, Fen Edebiyat Fakültesi, İngiliz Dili ve Edebiyatı Anabilim Dalı \\ serdaraltac@nevsehir.edu.tr \\ ORCID No: 0000-0002-6778-8571
}

\begin{abstract}
The aim of this study is to evaluate the concepts of sovereignty and bare life in Lord of the Flies written by the English novelist, William Golding. An evaluation of the novel with the understanding of sovereignty as it is put forward by the Italian political theorist Giorgio Agamben will demonstrate that the text can be read as the formation of civilization, contrary to the point of view that interprets the novel as the disappearance of civilization. To this end, the examples of the state of exceptions, which Agamben thinks are intimately related to the formation of sovereignty and law, in the novel demonstrated. According to this approach, the social order is enabled only through the state of exception. In the novel, this state becomes apparent with the suspension of law/rule and also the degradation of the human from political existence to bare life. After the novel is analyzed through these concepts, the island and the outside the island will be shown to be similar in terms of the state of exception with a specific emphasis on the relation between the novel and imperialist/ colonial biopolitics, and thus the novel cannot be read as the disappearance of civilization. In conclusion, it will be underlined that the violence-forged relations of stranded boys on the island become as such as a result of the nature of sovereignty and biopolitics.
\end{abstract}

Keywords: Lord of the Flies, Bare life, Sovereignty, Agamben, State of Exception.

\section{WILLIAM GOLDING'IN LORD OF THE FLIES ROMANINDA EGEMENLİK VE ISTISNA HALI}

Öz

Bu çalışmanın amacı İngiliz romancı William Golding'in Lord of the Flies (Sineklerin Tanrısı) adlı distopik romanındaki egemenlik ve çıplak yaşam kavramlarını incelemektir. İtalyan siyaset kuramcısı Giorgio Agamben'in egemenlik anlayışı ile bu romanın incelenmesi, romanı medeniyetin yok oluşu şeklinde yorumlayan bakış açısının tersine romanın medeniyetin oluşumuna dair bir metin olarak da okunabileceğini gösterecektir. Bu bağlamda, Agamben'in egemenliğin ve yasanın oluşumu ile yakından ilgili olduğunu düşündüğü istina hallerinin romandaki örnekleri ortaya koyulacaktır. Bu yaklaşıma göre toplumsal düzenin oluşumu ancak istisna halinin varlığı ile mümkündür. Bu hal, romanda kimi zaman bir yasanın/kuralın askıya alınması ile kimi zaman ise politik bir varlık olarak insanın çıplak yaşama indirgenmesi ile ortaya çıkmaktadır. Roman bu kavramlar ışığında incelendikten sonra ise romanın emperyalist ve sömürgeci biyosiyaset ile olan ilişkisi irdelenerek ada ve dış dünya arasında istisna hali bakımından bir fark olmadığı ve tam da bu nedenle adadaki olayların medeniyetin yok oluşu şeklinde yorumlanamayacağı ifade edilecektir. Sonuç olarak ise 1ssız 
bir adada mahsur kalmış bir grup çocuğun giderek şiddetle şekillenen ilişkilerinin egemenlik ve biyosiyasetin doğası gereği bu hale geldiği vurgulanacaktır.

Anahtar Kelimeler: Lord of the Flies, Çıplak Yaşam, Egemenlik, Agamben, İstisna Hali.

\section{INTRODUCTION}

Lord of the Flies (1954) by William Golding is a dystopian novel that relates the story of a group of British boys stranded on an island as a result of a plane crash. Assembling after the initial chaos in the aftermath of the crash, they elect Ralph as the leader of the group, albeit the nomination of Jack, who appears as the head of the choir at the beginning. After making sure that they are on an island, Ralph makes a division of tasks and assigns Jack and his group to keep a fire that would attract the attention of the passing ships. However, Jack, who seems to have autonomy in the group, forsakes the task in favor of hunting pigs with his own group, which causes a ship to pass by the island without noticing the call for help. As a result, Ralph and Piggy reprimand Jack for his irresponsibility. During the quarrel, Jack attacks Piggy and breaks one of his specs which they use as a tool to kindle a fire. This event ignites the deeper divisions within the group, for, while Ralph aims to establish an order that would facilitate their rescue from the island, Jack gives priority to an order that facilitates the fulfillment of their immediate needs. Meanwhile, the little boys, referred to as 'littluns' in the novel, begin to claim that there is a beast on the island that haunts them. After an aerial combat over the island, a parachutist glides down to the island and Samneric, the twins, confuse the dead body hanged to a parachute with the beast. Consequently, a hunting party including Jack and Ralph sets out to find the beast. On their return, Jack assembles a meeting to overthrow Ralph, accusing him of being a coward, yet he is unable to do it. Understanding that he cannot defeat Ralph, he leaves the camp and calls the hunters to join him. Jack declares himself as the leader of the new group. Meanwhile, Simon finds out that the beast is in fact a parachutist and goes to tell the truth to the others. However, Jack's group thinks Simon is the beast and savagely kills him. The next day, Jack's hunters raid Ralph's camp and seize Piggy's specs to light fire in their own camp. Ralph, with his group, arrives at Jack's camp to take the specs back; however, the confrontation gets violent and Piggy is killed by a rolling rock and Ralph is injured. The following day, Jack commands his group to hunt down Ralph. At the end of the chase, Ralph and the hunters encounter a British naval officer who came to the island due to smoke of the fire that Jack has started to catch Ralph.

The existing criticism on The Lord of the Flies has a strong tendency to associate the novel with regression into barbarism and state of nature in which Hobbes famous dictums that 'bellum omnius contra omnes' (the war of all against all) or 'homo homini lupus' (a man is a wolf to another man) hold sway (see Ariansen, 2010: 99; Yar, 2015: 25). However, as Leon Lewitt indicates, "the boys come to the island already acculturated. [...] They bring a tradition of carnivorous blood-lust, human violence, tribalism [and] ingenuity in warfare" (1969: 522). For that reason, the novel cannot be evaluated with a simple dichotomy of civilization and barbarism. The events on the island can be read as a reflection of the 'civilized' world from which the children come. This paper aims to show that the novel can also be read as a depiction of the foundation of sovereignty and social organization. To prove this, this paper engages with the concept of "state of exception" as theorized by Italian political philosopher Giorgio Agamben. To understand this concept, one first needs to understand the outlines of Agamben's political theory that he places upon the distinction zoe and bios. Agamben explains the long-forgotten difference as follows:

The Greeks had no single term to express what we mean by the word "life". They used two terms that, although traceable to a common etymological root, are semantically and morphologically distinct: zoe, which expressed the simple fact of living common to all living beings (animals, men, or gods), and bios, which indicated the form of way of living proper to an individual or group. (1998: 1)

Agamben grounds his theory of sovereignty on the distinction between zoe and bios. According to this, sovereign becomes as such inasmuch as it can play upon these characteristics. In a biopolitical context, bios designates the kind of life in which the individual is protected by law and its community. This way of life corresponds to the definition of man by Foucault, drawing on 
Aristotle, as "a living animal with additional capacity for political existence" (1978: 143). In a way that can be comparable to Habermas' distinction between public and private, zoe represents the life belonging to the private and reproductive sphere, oikos. According to Agamben, when the distinction between these two forms of life is blurred, when zoe is introduced into bios, or in other words, when life is politicized, a new form of life called "bare life" (nuda vita) appears. One of the most salient historical examples of such politicization can be observed in Nazi concentration camps where "the most absolute conditio inhumana that has ever existed on earth was realized (Agamben, 1998: 166). In these camps, to complete Foucault's statement, "modern man" becomes "an animal whose politics places his existence as a living being in question" (1978: 143). Although they had been fellow citizens of their country, the sovereign, through creating a state of exception, strips them of their rights and citizenship before the "final solution" (Agamben, 1998: 132). In this context, what defines the sovereign is the ability to decide on life and death as well as on the norm and state of exception, for "the state of exception, which is what the sovereign each and every time decides, takes place precisely when naked life is explicitly put into question (Agamben, 2000: 5). The example of genocide is an instance of the treatment of bare life in its extremity. However, Agamben traces the origin of this historical anomaly back to an ancient Roman legal figure called homo sacer. Homo sacer, explains Agamben, is someone "who may be killed [with impunity] yet not sacrificed [in the religious rituals]" (1998: 8), or as Zizek defines it, "although he or she is still alive as a human being, [homo sacer] is not a part of the political community" (2002: 91). The life is homo sacer is in a zone of indistinction. Law not only bans him/her from the polis but also captures him/her through the exclusion. Consequently, homo sacer is produced by a paradoxical process of inclusive exclusion: "by excluding it, it is also recognized" (Tumay and Mutlu, 2019: 258). Eventually, the sovereignty, regardless of the form of government, works through creating state of exceptions whereby laws are suspended and bare life is produced.

At this point, the relevance of Agambenian (bio)politics in interpreting Lord of the Flies becomes clear. The novel indeed foregrounds the violence-prone aspect of human nature. However, this proneness is also embedded in the structure of civilization and social organization. For that reason, this paper will seek to show that through states of exceptions and through the lives that are rendered exceptions, the novel portrays power relations of the 'civilized' world. The overarching question in this study is whether this violence proneness is a symptom of a shift away from civilization or an exposition of the inner workings of laws that constitutes civilization.

\section{THE STATE OF EXCEPTION IN THE NOVEL}

When Piggy and Ralph meet at the beginning of the novel, the first thing they look for is whether there are any grownup survivors. The obvious reason for this is that the adult world represents a social order which the children lack at the outset. However, soon after each child on the island rallies to Ralph's call, it becomes evident that they already have resources to build an adult world; to put it another way, a social organization with rules and regulations. Immediately, they set a meeting in which they elect the leader and the law-maker of the group. Yet, as the story unfolds the rules are revealed to be temporary and ignorable at the will of certain characters. What is at stake is not that the children lack the maturity to observe their own rules but the rules themselves are prone to be suspended by their very nature. One of the first legislative acts of Ralph as the elected leader of the group is about the rights of speech among the members. He states that:

We can't have everybody talking at once. We'll have to have 'hands up' like at school. [...] Then I'll give him the conch [...] I will give the conch to the next person to speak. He can hold it when he's speaking. [...] And he won't be interrupted. Except by me. (25)

What needs to be recognized in this speech is that law immediately creates its own exception. Although conch, as a token of law, provides its holder with a right to speak at that moment, Ralph secures his position as sovereign by highlighting his potential to suspend the law that he himself enforces. Ralph's rule that rules out itself is a perfect example of the definition of sovereignty by Carl Schmitt, whom Agamben uses as a theoretical framework. In his famous beginning to The 
Political Theology, Schmitt states that "[sovereign] is he who decides on the exception" (2005: 5). One of the explicit driving dualities expressed in the novel is that of democracy and totalitarianism. In his interpretation of the film version of Lord of the Flies, Diken and Laustsen rightly remark that "the conch is an instrument of democratic governance and legitimacy, a token necessary for preserving the agora and holding violence at bay" (2006: 432). However, Ralph's repudiation of the rule that he lays is an indication of an anti-democratic tendency embedded even in the democratic governments. The rule has the potential of suspending itself. For this reason, Ralph is both inside and outside the juridical order as the sovereign figure. However, the exception that the sovereign produces is not only a juridical concept but it also has a deep biopolitical dimension whereby bare life is produced. From the very beginning of the novel, although both of them act as the voice of reason, Ralph does not hesitate from ignoring and socially ostracizing Piggy. Their first meeting testifies to this exclusionary politics: "[Piggy] hesitated for a moment, then spoke again. 'What's your name?' 'Ralph.' The fat boy waited to be asked his name in turn but this proffer of acquaintance was not made" (3). Since Piggy is a 'negligible' figure, for reasons that will be explained below, Ralph does not deign to learn his name. Piggy's exclusion continues and even intensifies as the scattered boys on the island rallies to the voice of the conch. Although Piggy makes it clear to Ralph that 'Piggy' is a name that is not supposed to be disclosed to the other boys, Ralph reveals this unwanted nickname when everyone gathers around him. This transforms Piggy into an object of social derision in a more strict sense: "For the moment boys were a closed circuit of sympathy with Piggy outside: he went very pink, bowed his head and cleaned his glasses again" (14). As a result, Ralph who dedicates himself to be the founder of social cohesion among the boys ironically becomes the active agent who works with exclusionary logic that creates an exception. According to this logic, everyone, even Jack who is the apparent political foe of Ralph, is respectable members of the society, except for Piggy.

However, in several instances, Jack is the one who decides on the state of exception. Although Ralph is the elected governor of the group, he shares his power with Jack right at the moment of his election. Seeing Jack's mortified appearance after losing the election, Ralph grants him the administration of the choir: "'Jack's in charge of the choir. They can be- what do you want them to be?' 'Hunters.' Jack and Ralph smiled at each other with shy liking. The rest began to talk eagerly" (16). The importance of this scene is that Jack's later 'coup' can no longer be considered to be a simple rebellion to the sovereign, Ralph, because Jack already has the position of sovereign. And as the sovereign, he has the right to decide on the state of exception. In addition to bullying Piggy whenever he puts forward an opinion on the matters concerning the welfare of the group, Jack does not observe the meaning of the conch when Piggy holds it, which produces just another state of exception. Whenever Piggy tries to express his opinion, Jack aggressively intervenes into his speech:

'We haven't made a fire,' [Piggy] said, 'what's any use. We couldn't keep a fire like that going, not if we tried.' 'A fat lot you tried, 'said Jack contemptuously. 'You just sat.' 'I got the conch,' said Piggy indignantly. 'You let me speak!' 'The conch doesn't count on the top of the mountain,' said Jack, 'so you shut up!'. (33-34)

It is not that Jack aims to undermine all the social structures that Ralph has been trying to found, and later to drag the group into mere anarchy. Jack, who usurps Piggy's right to speak, agrees with Ralph on the importance of the rules: "We have got to have rules and obey them. After all, we are not savages. We are English, and the English are best at everything" (34). Jack's paradoxical attitude towards the rules echoes the sovereign's relation to the law: He is both inside and outside the law. His identity as being-outside-the-law facilitates the production of bare life which is ignorable when compared to a fellow 'citizen'. Jack's confrontation with Piggy and Ralph after he causes the signal fire to extinguish when a ship passes by illustrates a telling example of the difference between political life and bare life. Although Ralph reprimands Jack as severely as Piggy, Jack prefers to physically attack Piggy in the end.

The reason why Piggy is continually thrown into a state of exception can be explained by his name and his physical qualities. Piggy's name not only denotes his physical semblance but also to his liminal position between man and animal, putting him into a state of indistinction. In her seminal essay, Zeynep Z. Atayurt reveals the ways by which fat is socially constructed and how Lord of the 
Flies embodies a critique of such discourses through Piggy. As to the discourses that decry the fat she indicates that " 'fat' or 'obesity' has been stigmatized category at least since the early twentieth century. Those who do not conform to a narrow norm are seen as political, social, and even moral threats" (2010: 44). Piggy's physical traits, or zoe in Agambenian terms, at once become the focus of political calculations on the island. The narrator explains that "there had grown up tacitly among the biguns the opinion that Piggy was an outsider, not only by accent, which did not matter, but by fat, and ass-mar, and specs and a certain disinclination for manual labour" (54). He is stripped of his rights as a member of the group not because of the rationality or irrationality of his arguments but as a result of his deviance from the rest of the group in terms of his physical appearance. The absurdity of this treatment to Piggy is, indeed, what is deemed necessary for the constitution of group cohesion. "The so-called primitive savagery of Jack is recognizably 'civilized' in the way it draws on the fatphobic stereotypes that unite the community at the expense of the outsider, Piggy" (Atayurt, 2010: 57). Atayurt's statement confirms the paradox of violence lying at the heart of civilization. The process leading to Piggy's social ostracization is a result of a need for an "abject" figure whose expulsion would facilitate law and order in the community. The island that they colonize, which is a frequented topic in castaway narratives, does not harbor a native population, which they can exclude in order to consolidate their internal order. The result is a search for new 'other' and if it is not possible, make up new 'others'. When the novel is compared to Ballantyne's Coral Island, perhaps the most influential text on Lord of the Flies and also directly referred to in it, the issue of otherness becomes more explicit. Unlike Golding's text, in Coral Island, the British boys are in an opposition with the local 'savages' and pirates, due to which they have to keep a group cohesion.

At this juncture, the beast and the idea of otherness gains importance. One of the first rules that Jack declares when he founds his independent group is that nobody would seek to harm the beast in the forest and furthermore they would "leave some of the kill for it" (119). The paradoxical situation of the state of exception or homo sacer is once more emphasized by this legislation. Homo sacer, who is in the state of exception/nature, is indispensable for the formation of power by the sovereign, for the sovereign does not destroy a former state of nature to assert its own validity but creates this state by its own very nature. Contrary to common assumption, Jack can be considered to be the representative of order and civilization. His preference for meat over rescue during his early disputes with Ralph does not necessarily mean that he is being stripped of civilized qualities. Moreover, it is quite clear that even if they were rescued, they would return into a geography ridden by a war which is just another state of exception in which bare lives are produced. For that reason, the impeccable order that Jack and the choir demonstrates at the beginning is not something that Jack loses but exactly what he retains during the course of the novel. For the formation of the civilized order, Jack makes use of the imaginary threat, namely beast and the state of nature that it represents, through which he provides legitimacy for his rule. Agamben holds that "through the state of exception, the sovereign 'creates and guarantees the situation' that the law needs for its own validity" (1998: 17). Although Ralph seems to be at the opposite pole of the political axis on the island, he and Piggy join the feast held by Jack. Their sentiment about the atmosphere of the feast can also be read as the description of the sovereignty and the environment it creates. As the group starts doing the hunting dance, "Piggy and Ralph, under the threat of the sky, found themselves eager to take place in this demented but partly secure society" (135, italics mine). The sovereign has the ability to wield an arbitrary power on his subjects, which explains the 'demented' characteristic of the sovereign and the society, and the sovereign, thanks to the use of arbitrary power and his position outside the law, creates a feeling of protection against the imaginary threat, which explains 'partly secure' characteristic of the group. Diken and Laustsen evince that "Lord of the Flies is the allegory of a society in fear, a society that perceives security as its primary factor of organization" (2006: 436) and speaking generally of the nature of state of exception, they also suggest that "the state starts treating its own citizens as potential enemies, as outsiders. The distinction is blurred in that suddenly one's status as a citizen ceases to remain taken for granted and becomes something to be decided upon" (2005: 19). That is the reason why even those who have joined Jack's tribe are still vulnerable to atrocities inflicted by Jack. For example, Wilfred is tied up and beaten by Jack for no discernible reason. As Agamben states "sovereign is the one with respect to whom all men are potentially 
homines sacri" (1998: 84) and Jack instantiates this arbitrariness of violence by directing it to not only his apparent enemies but also to his apparent subjects.

After Piggy's death and Samneric's capture by Jack's group, Ralph remains completely alone and vulnerable. After the elimination of the beast, Jack needs to produce another bare life against whom he can mobilize sovereign violence. Thus, devoid of his polity and community, Ralph ideally suits to the figure of homo sacer or friedlos. Though he is ostracized from Jack's group "there was that indefinable connection between himself and Jack; who therefore would never let him alone; never" (166). The description of the relation between Jack and Ralph is reminiscent of Agamben's delve into the etymology of the word "exception" which comes from "ex-capere" and means "taken outside [...] not simply excluded" (1998: 18). The sovereign not only excludes homo sacer but it also captures him/his life in the outside. The vacant liminal position between human and animal left by Piggy is filled by Ralph. It is no coincidence that Roger sharpens a stick at both ends just before they set out to hunt down Ralph. They do not merely aim to kill Ralph, but stick his head to the spear and fix it into the ground as they did with a pig in the previous chapters. Thus, Ralph becomes a friedlos in that "he can save himself only in a perpetual flight or a foreign land" (Agamben 1998: 183). The narrator relates his predicament as follows:

\section{Ralph knelt among the shadows and felt his isolation bitterly. They were savages it was true; but they were human, and the ambushing fears of the deep night were coming on. Ralph moaned faintly. [...] Might it not be possible to walk boldly into the fort, say 'I've got pax,' laugh lightly and sleep among the others? [...] Lying there in the darkness he knew that he was an outcast. (167-168)}

As a person without peace, he is completely exposed to the risk of being hunted. That is the reason why he tries to figure out how a pig would think in its escape from the hunters, which is also a proof of his departure from the political domain and approach to animal domain.

The final scene of the novel has a subtle implication as to the parallelism between the state of exception founded by Jack and the state of exception founded by the adult world. When the naval officer finds Ralph he holds the butt of his revolver. Only when he recognizes that Ralph is not a native of the island, does he take his hand away from his gun. This short sequence of events is, in fact, an expression of the colonial biopolitics that has been in effect for centuries. The colonial logic of sovereignty functions in a way that far exceeds the arbitrariness of sovereign violence in the homelands. In The Wretched of the Earth, Franz Fanon indicates that "colonialism is not a machine capable of thinking, a body endowed with reason. It is naked violence" (2004: 23). Though Fanon's argument may be a little problematic in Agambenian sense, for the violence of the sovereign is based on a set of rational mechanisms, the purity of violence that he emphasizes can be observed in the violence directed against a homo sacer. The scene implies that if Ralph were a native, the officer would be likely to take out his revolver and probably shoot him with impunity. In The Origins of Totalitarianism, Hannah Arendt perfectly puts the biopolitical logic of colonialism as follows:

What made [the colonized subjects] different from other human beings was not at all the color of their skin but the fact that they behaved like a part of nature, that they treated nature as their undisputed master, that they had not created a human world, a human reality [....] They were, as it were, "natural" human beings who lacked the specifically human character, the specifically human reality, so that when European men massacred them they somehow were not aware that they committed murder. (1973: 192)

In this way, the distinction between the 'civilized' individuals outside the island and the 'savages' on the island becomes blurred. The acculturation that the boys received before they arrive in London was largely shaped by a civilization based on colonial practices that Arendt describes. Just as Jack treats Ralph as if he is in a state of nature where he is at a position between human and animal, the war burgeoning in the rest of the world implies that in the outside people treat each other exactly in the same way. War, which is a state of exception par excellence, suspends the laws condemning the murder. 


\section{CONCLUSION}

In conclusion, Lord of the Flies can be read as a novel that is mainly built on the concept of the state of exception. Each political and legislative act of the children create legal and (bio)political exceptions. This fact implies that despite the severity of violence among the children, the novel does not relate a shift away from civilization. Agambenian reading of the text shows that the novel exposes the inner workings of law, and civilization built upon it. Regardless of the form of governments, democratic and totalitarian ones represented by Ralph and Jack respectively, the sovereign produces exceptions. And the exception is a state in which homo sacer is created by downgrading the citizen into a state of nature. Evidently, the parallelism between the outside world and what happens on the island shows that the children have done exactly what the adults do in their lawful worlds. The island does not reveal a deep flaw in human nature but reveals the effects of order established by the children.

\section{REFERENCES}

Agamben, G. (1998). Homo Sacer: Sovereign Power and Bare Life. (Trans.) Daniel Heller-Roazen, Stanford: Stanford University Press.

Agamben, G. (2000). Means without End. (Trans.) Vincenzo Binetti and Cesare Casarino, Minneapolis: University of Minnesota Press.

Arendt, H. (1973). The Origins of Totalitarianism, San Diego: Harvest Book.

Ariansen, P. (2010). 'It is an Island!': Prospects for Life in Pristine Beginnings' In Rita Ghesquiere and Knut J. Ims (Eds.), Heroes and Anti-Heroes: European Literature and Ethics of Leadership (pp. 91-104), Antwerp: Garant.

Atayurt, Z. Z. (2010). 'Kill the Pig!': Lord of Flies, 'Piggy,' and Anti-Fat Discourse In Elena L. Navarro (Ed.), Historicising Fat in Anglo-American Culture (pp. 43-65), Columbus: Ohio State University Press.

Ballantyne, R. M. (1994). Coral Island, London: Penguin.

Diken, B. and Carsten, B. L. (2006). From War to War: The Lord of Flies as the Sociology of Spite Alternatives: Global, Local, Political, 31(4), 431-452.

Diken, B. and Carsten, B. L. (2005). The Culture of Exception: Sociology Facing the Camp. Oxon: Routledge.

Fanon, F. (2004). The Wretched of the Earth. (Trans.) Richard Philcox, New York: Grove Press.

Foucault, M. (1978). The History of Sexuality. Vol 1. (Trans.) Robert Hurley, New York: Pantheon Books.

Golding, W. (2001). Lord of the Flies. New York: Penguin.

Lewitt, L. (1969). Trust the Tale: A Second Reading of "Lord of the Flies". The English Journal, 58(4), 521533.

Schmitt, C. (2005). Political Theology: Four Chapters on the Concept of Sovereignty. (Trans.) George Schwab, Chicago: University of Chicago Press.

Tumay, M. and İsmail, M. (2019). Agamben's Critique of Human Rights. SDÜHFD, 9(2), 253-269.

Yar, M. (2015). Crime and the Imanigary of Disaster: Post-Apocalyptic Fictions and the Crisis of Social Order. Hampshire: Palgrave Macmillan.

Zizek, S. (2002). Welcome to the Desert of the Real, London: Verso. 


\section{GENIŞLETILMIŞ ÖZET}

\section{Amaç}

Bu çalışmada İngiliz romancı William Golding'in Lord of the Flies (Sineklerin Tanrısı) adlı eseri incelenmektedir. Söz konusu romanının yorumlanması genellikle medeniyetin kırılganlığ 1 veya insanın şiddete meyilli sorunlu doğası gibi tartışmalar üzerinden gerçekleştirilmektedir. Ancak bu çalışma, mevcut okumaların tersine bir yaklaşım getirmeyi amaçlamaktadır. Bu çalışmanın amacı romanda gözlemlenen şiddetin aslında kuralların ve yasaların bir çeşit yan etkisi olduğunu göstermektir. Bu kavramlar ile tanımlanabilecek medeniyet, adada yok olduğu için değil; tam tersine varlığını sürdürdüğü için bir şiddet ortamı zaman içinde adayı hâkimiyeti altına almıştır.

\section{Metodoloji}

$\mathrm{Bu}$ çalışmanın kuramsal çerçevesini İtalyan siyaset kuramcısı Giorgio Agamben'in egemenlik ve istisna hali kavramları oluşturmaktadır. Agamben'e ve kuramının temellerinden birini oluşturan Carl Schmitt'in anlayışına göre egemen, ancak istina hallerine karar verebildiği sürece egemen olarak tanımlanabilir. Bu yaklaşıma göre egemen, aynı anda hukukun hem içinde hem de dışındadır. Nitekim egemen, yasalara aykırı olarak değil; bizzat yasaları kullanarak yasaları askıya alabilen kişidir. Egemenliğin bu çelişkili yapısı Hobbes'un ifade ettiği doğal hal ve egemenlik arasında da gözlemlenmektedir. Egemen, doğa halini dışlar ancak egemen, egemen olmadan önce veya medeniyetten önce doğa hali olarak adlandırılabilecek bir hal de yoktur. Agamben, doğa hali ve istisna hali gibi kavramlan benzer anlamlara gelecek şekilde kullanır. Bu hallerin somutlaştı̆g tarihsel bir figür olan homo sacer (kutsal insan) Agamben'in kuramında merkezi bir konumdadır. Roma hukukuna dayandırılan bu figür Batı toplumlarının biyopolitik yapısında da önemli bir yer tutmaktadır. Dini ritüellerde kurban edilmesi yasak olan ancak öldürülmesi de kanunların suç olarak değerlendirmediği kişi olan kutsal insan kanunlar yoluyla kanunun dışına çıkarılmıştır. Bu kişi, artık bir zamanlar kendisini ve hayatını koruma altında tutan topluluğun bir üyesi değil; bu topluluğun keyfi olarak öldürebileceği bir figür haline dönüşmüştür. Kutsal insan kendisine karşı herkesin egemen olduğu; egemen ise nezdinde herkesin kutsal insan olabileceği kavramlara işaret eder (Agamben 1998: 84).

Yukarıda belirtilenler dikkate alındığında medeniyet ve barbarlık tartışmalarını merkezine yerleştiren bir roman olan Lord of the Flies'in Agamben'in egemenlik anlayış1 1şığında incelenmesi romandaki egemenlik kavramını ve biyopolitik yaklaşımları anlamak açısından önem arz etmektedir. Birbiri ile zit kavramlar olarak algılanan şiddet ve medeniyeti neredeyse ayrılmaz olarak algılayan bu yaklaşım, bu romanda var olduğu düşünülen klasikleşmiş̧ ikili karşıtlıkların tersine bir okuma imkânı sağlayacaktır. Bu bağlamda romanda egemen kimliği üzerinde durulacak ve aynı zamanda istisna hali olarak kabul edilebilecek durumlar ortaya koyulacaktır.

\section{Bulgular}

Romanda geçen olaylar yetişkinlerin dünyasından bağımsız olarak değil bizzat yetişkinlerin dünyasında meydana gelen oluşumların bir yansıması olarak değerlendirilmiştir. $\mathrm{Bu}$ anlamda romanın başında grubun lideri olarak seçilen Ralph karakteri ve daha sonradan kendi topluluğunu oluşturmak üzere Ralph'in grubundan ayrılan Jack iki farklı egemen figür olarak görülmektedir. Her ne kadar Ralph, demokratik bir düzenin simgesel figürü; Jack ise daha baskıcı ve totaliter bir düzenin temsilcisi olarak değerlendirilebilse de her ikisi de yönetim şekillerinden bağımsız olarak egemendirler ve Agamben'in egemenlik kavramında da ifade ettiği üzere doğaları gereği istisna halleri yaratırlar.

Ralph ilk istisna halini çelişkili bir şekilde koyduğu kuralla birlikte yaratır. Deniz kabuğunu tutan kişinin konuşma hakkına sahip olacağını belirten Ralph, bu hakkı kendisinin gerekli gördüğü anlarda geri alabileceğini belirterek egemenin istisna halindeki veya olağan üstü haldeki davranışına bir örnek teşkil eder. Buna ek olarak Ralph ve Piggy arasındaki ilişki de egemen ve kutsal insan arasındaki ilişkiye benzemektedir. Her ne kadar Jack'in bir egemen olarak daha sonradan göstereceği derecede bir saldırganlık göstermese de, Ralph romanın en başından itibaren Piggy'i dışlar ve bu dışlanmışlık hali diğer çocuklar arasında belirli bir grup kimliğinin oluşumunu sağlar. Fiziksel özellikleri bakımından diğer çocuklardan farklı olan Piggy, ismi itibariyle de hayvan ve insan arasındaki bir noktada bulunarak kutsal insanın kanunlar ile olan ilişkisindeki konumunu işgal eder. 
Çocukların ormanın derinliklerinde yaşadığına inandıkları canavar ise egemen figürün ürettiği ve faydalandığı kutsal insan ile benzeşmektedir. Aslında varlığına inanılan bu canavar, tam olarak bir insan şeklinde düşünülmese bile, kutsal insanın ortaçağdaki karşılığı olan kurt adam figürü ile benzeşmektedir. Özellikle Jack' in Ralph'den ayrılıp kendi grubunu kurması ile başlayan süreçte canavarı avlamaya çalışmak yerine ona domuz avından parçalar bırakması istisna hali veya doğa hali olarak değerlendirilebilecek canavarın varlığının önemini kanıtlamaktadır.

Diğer bir taraftan ise metin, emperyalist ve sömürgeci Batı tarihi ile iç içe geçmiş bir söylem ile diyalog halindedir. Sömürgecilik politikalarının biyopolitik yönü ise egemenliğin oluşumu açısından oldukça belirgin bir örneği gözler önüne sermektedir. Sömürgeci biyopolitika ve adadaki olaylar arasındaki paralellik, adadaki olayların Batı medeniyetinden bir uzaklaşmadan çok Batı medeniyetinin bir yansıması olarak değerlendirilebileceğini göstermektedir.

\section{Sonuç ve Tartışma}

Sonuç olarak, William Goldin'in Lord of Flies romanında egemenlik ve toplumsal düzenin Agamben'e göre ayrılmaz bir parçası olan istisna halinin örnekleri gözlemlenmiştir. Yetişkin dünyasından uzak olsalar da çocukların koyduğu ve uygulanması hususunda mutabık kaldıkları her kural (biyo)politik istisnalar yaratmıştır. Bu bağlamda romanda ortaya çıkan şiddet, aslında medeniyetten bir uzaklaşma değil medeniyetin bir sonucu olarak yorumlanmıştır. Bu çerçevede birbirinden tamamen farklı iki yönetim biçimini temsil eden Jack'in ve Ralph'in kendi yönetimlerinde istisna halleri yaratmaları, yönetim biçimlerinden bağımsız olarak egemenin doğası gereği istisnalar yarattığını göstermiştir. Her iki yönetim de istisna halinin içine koyduğu kişileri topluluğun politik koruma alanı dışına iterek çıplak yaşamları ile baş başa kalan bu kişileri kutsal insan konumuna indirgemiştir. İstisna hallerinin en belirginlerinden biri olan savaşın yetişkinlerin dünyasında devam ediyor olması ise adada yaşananları farklı bir bakış açısı ile yorumlamayı gerekli kılmıştır. Medeni olduğu düşünülen yetişkin dünyasındaki şiddet ile çocukların dünyasında gözlemlenen şiddet arasındaki benzerlik adada medeniyetin yok olmadığını, sadece medeniyetin işleyişinin romanda daha 'çıplak' bir şekilde yansıtıldığını göstermiştir. 